\title{
THE ENHANCEMENT OF UNDERSTANDING CONCEPT OF FORCE THROUGH PREDICT OBSERVE EXPLAIN (POE) MODEL
}

\section{Lelyta Anggraeny, Peduk Rintayati, Muhammad Shaifuddin}

Universitas Sebelas Maret

lelytaanggraeny@gmail.com

\section{Article History}

accepted 09/07/2018

approved 01/08/2018

published 17/09/2018

\section{Keywords}

conceptual understanding, force, Predict Observe Explain (POE)

\begin{abstract}
The purpose of this research was to improve understanding of the concept of force through Predict Observe Explain (POE) Model to the students in grade IV of State Primary School 1 of Munggung Surakarta in Academic Year 2017/2018. The form of this research was a Classroom Action Research which conducted in two cycles. Each cycle consisted of four stages i.e. planning, action, observation, and reflection. The subjects of this research included teacher and students as many as 20 in Grade IV of the aforementioned school in Academic Year 2017/2018. The data collected by interview, observation, test, and documentation techniques. The data validity test were using content validity, triangulation of resource, and triangulation of technique. The result of this research shows that in each cycle there is an improvement in the conceptual understanding values from pre-action, cycle I until cycle II.
\end{abstract}

Social, Humanities, and Education Studies (SHEs): Conference Series https://jurnal.uns.ac.id/shes
p-ISSN 2620-9284 e-ISSN 2620-9292 


\section{PENDAHULUAN}

Ilmu Pengetahuan Alam (IPA) adalah salah satu ilmu pengetahuan yang diberikan pada hampir semua jenjang pendidikan, termasuk pada pendidikan sekolah dasar. IPA mempunyai peranan penting dalam peningkatan mutu pendidikan. Terutama di dalam menghasilkan siswa yang berkualitas, di antaranya yaitu menjadi manusia yang kreatif, inovatif dalam menanggapi dampak perkembangan ilmu pengetahuan dan teknologi, serta mampu berpikir logis dan kritis. Maka dari itu, pelajaran IPA harus benar-benar diperhatikan dalam setiap pembelajarannya.

Trianto (2013) bahwa IImu Pengetahuan Alam adalah suatu kumpulan teori yang sistematis, penerapannya secara umum terbatas pada gejala-gejala alam, lahir dan berkembang melalui metode ilmiah seperti observasi dan eksperimen serta menuntut sikap ilmiah seperti rasa ingin tahu, terbuka, jujur, dan sebagainya. Wisudawati (2014) menambahkan dalam proses pemahaman konsep sains harus memenuhi pendekatan konstruktivisme Pendekatan ini menyatakan seorang siswa dalam memahami suatu konsep dengan membangun sendiri konsep-konsep tersebut dengan adanya pengaruh dari prakonsepsi yang dimilikinya. Siswa akan mendapatkan pengalaman langsung melalui kegiatan diskusi, pengamatan, dan penyelidikan sederhana. Pembelajaran seperti inilah yang bisa menumbuhkan sikap ilmiah siswa yang diindikasikan dengan merumuskan masalah, menarik kesimpulan, sehingga siswa dapat berpikir kritis melalui pembelajaran IPA. Oleh karena itu, pembelajaran IPA seharusnya dirancang menjadi pembelajaran yang menyenangkan, menarik, dan lebih mengaktifkan siswa selama pembelajaran. Hal ini dikarenakan siswa pada dasarnya mempunyai sifat aktif dan dapat merencanakan sesuatu untuk mencari, menemukan, dan menggunakan pengetahuan yang telah diperolehnya.

Pemahaman konsep merupakan hal yang paling penting dalam suatu pembelajaran karena bertujuan untuk mengerti dan memahami tujuan pembelajaran. Jika pada tahap pemahaman konsep siswa mempunyai hasil belajar rendah, siswa akan mengalami kesulitan dalam menghadapi tahap pembelajaran yang selanjutnya karena antara satu konsep dengan konsep yang lain akan selalu berkesinambungan. Salah satu konsep yang penting diajarkan kepada siswa yaitu konsep tentang gaya. Gaya merupakan salah satu materi di dalam ruang lingkup pembelajaran IPA SD untuk siswa kelas IV di dalam KTSP. Materi gaya dalam pembelajaran IPA SD terdapat pada Standar Kompetensi (SK) nomor 7 yaitu; "memahami gaya dapat mengubah gerak dan/atau bentuk suatu benda". Materi gaya sangat penting bagi siswa, karena sering ditemui dalam kehidupan sehari-hari siswa. Melalui pembelajaran materi gaya, diharapkan siswa dapat memahami dan menerapkannya untuk memecahkan masalah yang mereka hadapi.

Berdasarkan observasi proses pembelajaran yang dilaksanakan di kelas IV SD Negeri Munggung 1 Surakarta pada tanggal 17 Januari 2018, ditemukan permasalahan bahwa pembelajaran selama ini belum melibatkan siswa secara aktif dan pembelajaran masih berpusat pada guru. Selama ini guru belum menggunakan model pembelajaran yang inovatif, guru masih menggunakan metode ceramah dan pemberian tugas dalam menyampaikan materi kepada siswa. Selain itu, hambatan yang dihadapi yaitu masih kurangnya penggunaan media yang inovatif dalam pembelajaran IPA. Guru menjelaskan materi kepada siswa dengan media gambar seperti yang ada dalam buku pegangan siswa saja dan siswa belum pernah dilibatkan dalam sebuah praktikum. Hal ini membuat siswa terkesan malas dan kurang menaruh perhatian terhadap proses pembelajaran. Dengan proses pembelajaran tersebut pemahaman siswa akan sulit tumbuh dan berkembang karena siswa hanya akan menghafal dan mengingatnya dalam memori jangka pendek saja sehingga menyebabkan rendahnya pemahaman konsep gaya. 
Berdasarkan wawancara yang dilakukan pada tanggal 11 Januari 2018 dengan guru kelas IV, dalam pembelajaran IPA hanya beberapa siswa yang aktif bertanya. Siswa kurang berpartisipasi selama proses pembelajaran berlangsung karena siswa hanya mendengarkan penjelasan dari guru dan membuat siswa menjadi bosan. Penggunaan media pembelajaran yang menarik masih jarang digunakan oleh guru, sehingga pembelajaran kurang berkesan pada siswa.

Fakta lain yang menunjukkan rendahnya pemahaman konsep gaya pada siswa kelas IV SD Negeri Munggung 1 Surakarta tahun ajaran 2017/2018 dapat terlihat dari hasil uji pratindakan yang dilaksanakan pada hari Rabu, 17 Januari 2018. Hasil uji pratindakan pada pemahaman konsep gaya siswa termasuk dalam kategori rendah. Dari 20 siswa hanya 3 siswa atau 15\% saja yang tuntas dan mendapatkan nilai di atas KKM dengan rata-rata nilai sebesar 54,35. Kriteria Ketuntasan Minimal untuk mata pelajaran IPA adalah 70. Berdasarkan permasalahan tersebut, maka diperlukan upaya untuk mengatasi permasalahan pembelajaran IPA di kelas IV SD Negeri Munggung 1 Surakarta. Upaya yang hendak dilaksanakan oleh peneliti adalah dengan menerapkan model pembelajaran yang bisa meningkatkan hasil belajar dan partisipasi siswa dalam materi gaya.

Dalam hal ini salah satu model pembelajaran yang tepat yaitu dengan menggunakan model Predict Observe Explain (POE). Karamustafaoğlu dan Mamlok (2015) dalam jurnalnya menjelaskan "The POE strategy is an inevitable way to make science courses more interesting, to induce permanent learning and to eliminate misconceptions". Dapat diartikan bahwa model POE dapat membuat pembelajaran menjadi lebih menarik dan bermakna dan menghilangkan kesalahpahaman siswa mengenai konsep yang diterima dalam pembelajaran.

Sreerekha, dkk (2016) menyebutkan tiga langkah model POE: "The POE requires three tasks to be carried out first; this strategy helps to uncover individual students predictions, and their reasons for making these about a specific event. Second, students describe what they see in the demonstration-observation. Thrid, students must reconcile any conflict between their prediction and observation explaination." Dapat diartikan bahwa strategi POE mewajibkan siswa untuk melakukan tiga tugas. Yaitu yang pertama, membantu mengungkap prediksi siswa tentang suatu peristiwa dan alasan mereka membuat prediksi tersebut. Kedua, siswa menjelaskan apa yang mereka lihat dalam demonstrasi dan pengamatan. Ketiga, siswa harus menyatukan perbedaan yang ada antara prediksi dan observasi yang telah dilakukan.

Penggunaan model Predict Observe Explain (POE) dalam pembelajaran IPA materi gaya melibatkan secara maksimal seluruh kemampuan siswa dalam mencari tahu dan menyelidiki sesuatu secara logis, kritis, dan sistematis. Melalui penerapan model Predict Observe Explain (POE) diharapkan siswa bisa memprediksi pengaruh apa saja yang dapat ditimbulkan oleh gaya pada sebuah benda. Kemudian siswa melakukan pengamatan untuk membuktikan prediksinya tersebut. Selanjutnya siswa melakukan diskusi mengenai fenomena yang sudah diamati serta membandingkan hasil pengamatan dengan prediksi sebelumnya. Pada akhirnya pemahaman konsep gaya pada siswa dapat meningkat dikarenakan siswa terlibat secara aktif dalam proses pembelajaran.

Kelebihan model Predict Observe Explain (POE) diantaranya: 1) merangsang kreativitas siswa dalam mengajukan prediksi; 2) membuat pembelajaran menjadi lebih menarik karena siswa mengamati secara langsung peristiwa yang terjadi dalam eksperimen; 3) siswa mempunyai kesempatan untuk membandingkan teori dan kenyataan karena siswa mengamati secara langsung fenomena yang ada.

Berdasarkan uraian latar belakang tersebut, peneliti melakukan Penelitian Tindakan Kelas dengan judul "Peningkatan Pemahaman Konsep Gaya Melalui Model Predict Observe Explain (POE) Siswa Kelas IV SD Negeri Munggung 1 Surakarta Tahun Ajaran 2017/2018". Peneliti juga menyusun rumusan masalah penelitian yaitu 
"Apakah penerapan model Predict Observe Explain (POE) dapat meningkatkan pemahaman konsep gaya pada siswa kelas IV SD Negeri Munggung 1 Surakarta tahun ajaran 2017/2018?". Berdasarkan rumusan masalah tersebut, tujuan penelitian ini adalah untuk meningkatkan pemahaman konsep gaya dengan penerapan model Predict Observe Explain (POE) pada siswa kelas IV SD Negeri Munggung 1 Surakarta tahun pelajaran $2017 / 2018$.

\section{METODE}

Bentuk penelitian ini adalah Penelitian Tindakan Kelas (PTK) yang dilakukan di SD Negeri Mungging 1 Surakarta pada bulan Januari-Juni 2018. Subjek penelitian ini adalah siswa kelas IV yang berjumlah 20 siswa, terdiri dari 15 siswa laki-laki dan 5 siswa perempuan. Semua siswa memiliki kondisi fisik dan kejiwaan yang sehat, dengan kata lain tidak ada siswa yang berkebutuhan khusus. Teknik pengumpulan data yaitu melalui observasi, wawancara dan doku-mentasi. Uji validitas data dilakukan dengan triangulasi dan validitas isi. Penelitian ini menggunakan teknik analisis data model interaktif Miles dan Huberman dalam Sugiyono (2015: 337) yang terdiri dari tiga tahap, yaitu data reduction, data display, dan conclusion drawing/ verification. Indikator kinerja penelitian ini adalah peningkatan pemahaman konsep gaya siswa dalam mata pelajaran IImu Pengetahuan Alam dengan ketercapaian target $80 \%$ jumlah siswa di kelas. Peningkatan pemahamana konsep gaya diukur melalui tes pemahaman konsep pada setiap akhir pertemuan.

\section{HASIL DAN PEMBAHASAN}

Penelitian ini dilaksanakan dalam 2 siklus. Setiap siklus terdiri dari 2 kali pertemuan dengan alokasi waktu 2×35 menit pada setiap pertemuan. Materi yang dipelajari dalam penelitian ini yaitu gaya dapat mengubah gerak/bentuk suatu benda.

Berdasarkan hasil penelitian tindakan kelas baik siklus I, siklus II serta perbandingan antarsiklus yang telah dijelaskan sebelumnya, hasil analisis data penelitian dapat dirangkum dalam tabel 4.1 sebagai berikut.

Tabel 1. Rekapitulasi Hasil Analisis Data

\begin{tabular}{lccc}
\hline \multicolumn{1}{c}{ Keterangan } & Pratindakan & Siklus I & Siklus II \\
\hline Nilai Rata - Rata & 54,35 & 70,7 & 76,25 \\
Persentase Ketuntasan & $15 \%$ & $55 \%$ & $85 \%$ \\
Nilai Kinerja Guru & - & 2,72 & 3,04 \\
Nilai Afektif Siswa & - & 6,28 & 7,9 \\
Nilai Psikomotorik siswa & - & 6,2 & 8,5 \\
KKM= 70 & & & \\
Indikator Ketercapaian= 80\% & & &
\end{tabular}

Berdasarkan tabel, hasil penelitian menunjukkan adanya peningkatan pada setiap tindakan dari pratindakan, siklus I, dan siklus II. Peningkatan tersebut terjadi pada nilai rata-rata kelas, persentase ketuntasan, kinerja guru, nilai afektif siswa, dan nilai psikomotorik siswa. Penelitian Tindakan Kelas ini dilaksanakan dalam dua siklus dengan menerapkan model Predict Observe Explain (POE) untuk meningkatkan pemahaman konsep gaya siswa kelas IV SD Negeri Munggung 1 Surakarta. Berdasarkan perhitungan nilai pemahaman konsep gaya siswa yang memperoleh nilai di atas KKM $(\geq 70)$ menunjukkan adanya peningkatan. Sebelum tindakan nilai rata-rata 54,35 dengan persentase ketuntasan klasikal 15\%, pada siklus I nilai rata-rata meningkat menjadi 70,7 dengan persentase ketuntasan klasikal 55\%, dan pada siklus II mengalami peningkatan lagi menjadi 76,25 dengan persentase ketuntasan klasikal 85\%. Hal ini merefleksikan bahwa dengan penerapan model Predict Observe Explain (POE) dalam pembelajaran IPA materi gaya pada siswa kelas IV SD Negeri Munggung 
1 Surakarta tahun ajaran 2017/2018 dinyatakan berhasil, karena secara klasikal menunjukkan adanya peningkatan nilai pemahaman konsep gaya serta telah melebihi indikator kinerja yang telah ditetapkan yaitu sebesar $80 \%$. Dapat dilihat pada Gambar 1 sebagai berikut.

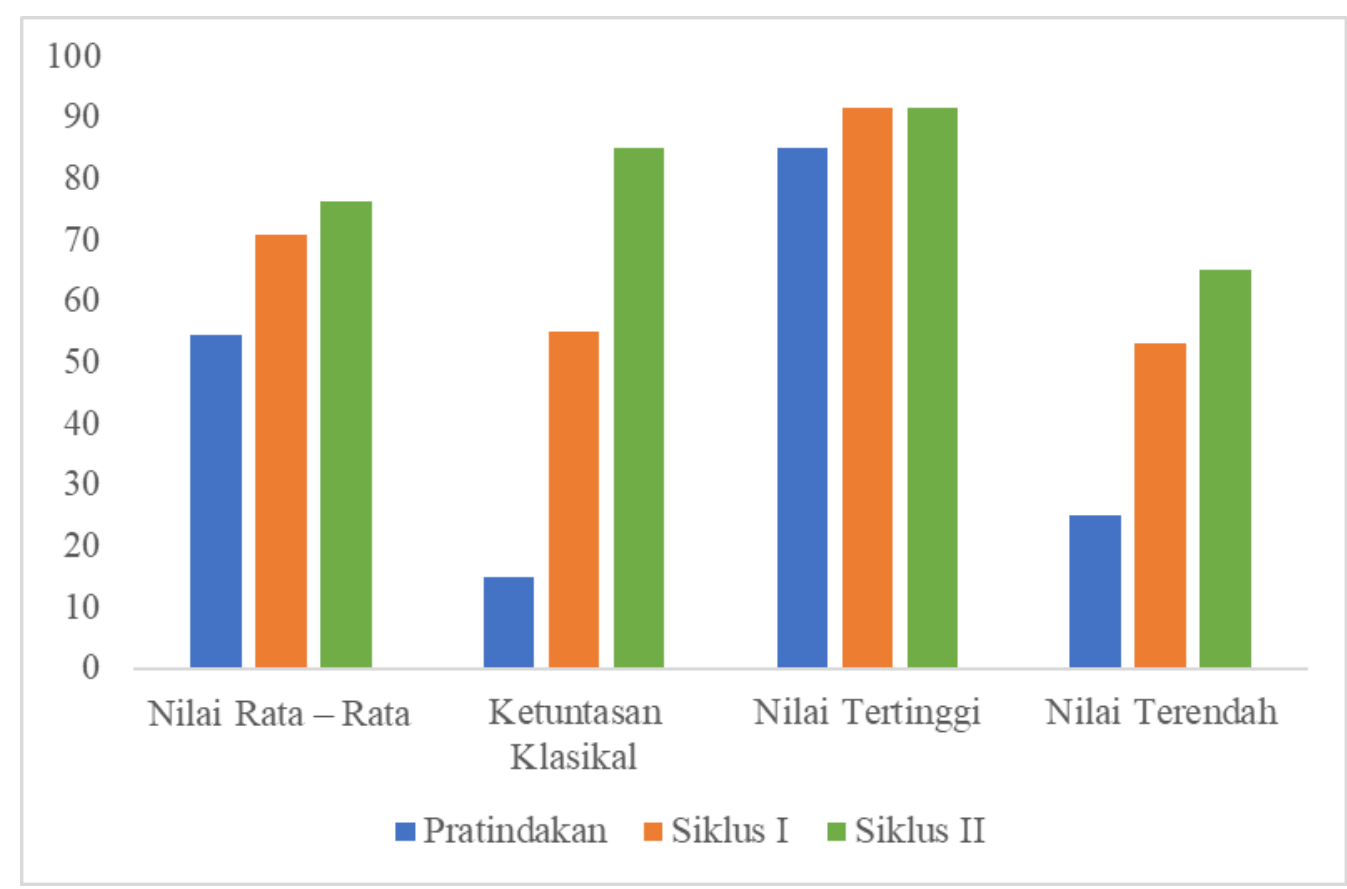

Gambar 1 Perbandingan Nilai Pemahaman Konsep Gaya Antarsiklus

Selain itu, kinerja guru dalam melakukan kegiatan pembelajaran juga mengalami peningkatan. Dari data hasil observasi guru diketahui bahwa terdapat peningkatan dari siklus I ke siklus II. Pada siklus I nilai kinerja guru yaitu 2,72 dengan kategori cukup baik dan pada siklus II mengalami peningkatan nilai kinerja guru yaitu 3,04 dengan kategori baik.

Penerapan model Predict Observe Explain (POE) pada materi gaya masih memiliki kendala pada siklus I dan siklus II. Kendala yang dialami pada siklus I dapat diperbaiki pada siklus II. Adapun kendala yang dihadapi yaitu: pada saat pelaksanaan diskusi, siswa masih terlihat ragu dalam menyampaikan pendapatnya, ramai sendiri, dan masih ada siswa yang menggantungkan jawabannya kepada teman diskusinya. Saat perwakilan kelompok maju untuk mempresentasikan hasil pengamatan, masih ada anggota kelompok lain yang tidak memperhatikan dan membuat gaduh kelas. Selain itu kendala yang dihadapi oleh peneliti dalam menyampaikan penjelasan atau perintah masih terlihat kaku dan kurang luwes. Kekurangan lain ketika mengajar yaitu, peneliti kurang memberikan motivasi dan penguatan pada siswa, sehingga partisipasi siswa masih rendah dan guru masih terlihat mendominasi pembelajaran. Guru harus meningkatkan kemampuan diri dalam mengajar terutama dalam penguasaan kelas dan juga penggunaan bahasa lisan dan tulisan secara jelas dan baik. Untuk memperbaiki kekurangan-kekurangan yang ada di siklus I, maka di siklus II disempurnakan dengan cara guru lebih memotivasi siswa agar berani mengemukakan pendapat serta guru harus lebih tegas kepada siswa yang ramai sendiri ketika pelaksanaan pembelajaran.

Peningkatan kinerja guru berpengaruh pada aspek afektif dan psikomotorik siswa. Dengan diterapkannya model Predict Observe Explain (POE), nilai afektif dan nilai psikomotorik siswa mengalami peningkatan. Kelebihan dari model Predict Observe Explain (POE) menurut Joyce (2006) dalam Yupani, Garminah, dan Mahadewi (2013) salah satunya yaitu proses pembelajaran menjadi lebih menarik 
karena peserta didik tidak hanya mendengarkan, tetapi juga mengamati peristiwa yang terjadi melalui percobaan atau eksperimen. Hal itu juga sesuai dengan pendapat Warsono dan Hariyanto (2013) yang menyatakan bahwa keberhasilan penerapan Predict Observe Explain (POE) dikarenakan setiap siswa diberi kesempatan secara langsung untuk melakukan demonstrasi. dengan adanya pengalaman langsung melalui percobaan inilah siswa menjadi lebih tertarik dan semangat dalam mengikuti pembelajaran. Skor rata-rata afektif siswa pada siklus I yaitu 6,28 dan mengalami peningkatan pada siklus II yaitu menjadi 7,9. Skor rata-rata psikomotorik siswa juga mengalami peningkatan. Pada siklus I skor rata-rata psikomotorik siswa yaitu 6,2 dan pada siklus II mengalami peningkatan menjadi 8,5.

Dari penelitian tindakan kelas yang telah dilaksanakan dalam dua siklus, dapat disimpulkan bahwa penerapan model Predict Observe Explain (POE) dapat meningkatkan pemahaman konsep gaya pada siswa kelas IV SD Negeri Munggung 1 Surakarta tahun ajaran 2017/2018.

\section{SIMPULAN}

Berdasar pada hasil penelitian tindakan kelas yang sudah dilakukan selama dua siklus dalam pelajaran Ilmu Pengetahuan Alam (IPA) dengan materi gaya melalui penerapan model Predict Observe Explain (POE) pada siswa kelas IV SD Negeri Munggung 1 Surakarta tahun ajaran 2017/2018, dapat ditarik simpulan bahwa penerapan model Predict Observe Explain (POE) dapat meningkatkan pemahaman konsep gaya pada siswa kelas IV SD Negeri Munggung 1 Surakarta tahun ajaran 2017/2018.. Implikasi dari penelitian ini membutikan bahwa dengan diterapkanya model Predict Observe Explain (POE) pada materi gaya dapat berkembang serta dapat meningkatkan kualitas pembelajaran. Berkaitan dengan hasil penelitian, peneliti mengajukan saran 1) bagi guru, sebaiknya mengupayakan tindak lanjut terhadap pembelajaran dengan menerapkan model Predict Observe Explain (POE) pada pembelajaran yang akan dilaksanakan berikutnya, 2) bagi sekolah, sebaiknya sekolah berupaya meningkatkan kualitas pembelajaran dengan mengadakan pelatihan bagi guru dalam menerapkan model pembelajaran yang inovatif 3) Bagi peneliti lain penerapan model Predict Observe Explain (POE) tidak hanya digunakan dalam mata pelajaran IPA materi gaya, akan tetapi bisa digunakan dalam materi atau mata pelajaran lainnya

\section{DAFTAR PUSTAKA}

Karamustafaoglu, \& Mamlok. (2015). Understanding Electrochemistry Concepts using the Predict-Observe-Explain Strategy. Eurasia Journal of Mathematics, Science \& Technology Education, 11(5), 923-936

Sreerekha, S., Arun, Raj., \& Swapna Sankar. (2016). Effect of Predict-Observe-Explain Strategy on Achievement in Chemistry

Sugiyono. (2015). Metode Penelitian Pendidikan Pendekatan Kuantitatif, Kualitatif, dan R\&D. Bandung: Alfabeta

Trianto. (2013). Model Pembelajaran Terpadu: Konsep, Strategi, dan Implementasinya dalam Kurikulum Tingkat Satuan Pendidikan (KTSP). Jakarta: PT Bumi Aksara

Warsono \& Hariyanto. (2013). Pembelajaran Aktif. Bandung: Remaja Rosdakarya

Wisudawati, Asih Widi, \& Sulistyowati, Eka. (2014). Metodologi Pembelajaran IPA. Jakarta: Bumi Aksara

Yupani, Garminah, Mahadewi. (2013). Pengaruh Model Pembelajaran PredictObserve-Explain (POE) Berbantuan Materi Bermuatan Kearifan Lokal terhadap Hasil Belajar IPA Siswa Kelas IV. Singaraja: Undiksha 